\title{
Does intravenous dexamethasone prevent nausea and vomiting after reduction mammoplasty?
}

\author{
Nicola Campbell MB ChB FRCA, Gregory L Bryson MD FRCPC, Ola Rosaeg MB FRCPC, \\ Mary Lou Crossan MLT BA, Paul Bragg MD FRCPC, Michael Bell MD FRCSC
}

N Campbell, GL Bryson, O Rosaeg, ML Crossan, P Bragg, $M$ Bell. Does intravenous dexamethasone prevent nausea and vomiting after reduction mammoplasty? Can J Plast Surg 2002;10(5):206-209.

BACKGROUND: Postoperative nausea and vomiting (PONV) is a common and unpleasant experience for patients after reduction mammoplasty. PONV may delay discharge from hospital. Dexamethasone is an effective and widely used antiemetic. OBJECTIVES: This study was designed to evaluate the efficacy of dexamethasone as a single antiemetic agent to reduce the incidence of PONV in patients undergoing reduction mammoplasty. METHODS: Fifty women scheduled for reduction mammoplasty were randomly assigned to receive either intravenous dexamethasone $0.150 \mathrm{mg} / \mathrm{kg}$ or saline before the induction of anesthesia. Postoperative analgesia was provided with intravenous morphine via a patient controlled device and rectally administered indomethacin. The presence or absence of nausea, retching and vomiting, and pain scores were assessed upon arrival in the postanesthesia care unit and at 2, 6, 8 and $12 \mathrm{~h}$, and by phone interview at 24 and $48 \mathrm{~h}$ after surgery.

RESULTS: The two groups were comparable in terms of age, history of motion sickness, duration of anesthesia and opioid consumption, both intraoperatively and postoperatively. There was no difference in the incidence of PONV between the two groups, but the patients who received dexamethasone required fewer doses of rescue antiemetic medication.

CONCLUSION: Intravenous dexamethasone before the induction of anesthesia is ineffective as a single agent antiemetic prophylactic treatment in patients undergoing reduction mammoplasty.

Key Words: Dexamethasone; Postoperative nausea and vomiting; Reduction mammoplasty

Résumé à la page suivante

Department of Anesthesiology and the Division of Plastic Surgery, The Ottawa Hospital Civic Campus, University of Ottawa, Ottawa, Ontario, K1Y 4E9

Correspondence: Dr Ola Rosaeg, Department of Anesthesiology, The Ottawa Hospital Civic Campus, University of Ottawa, 1053 Carling Avenue, Ottawa, Ontario K1Y 4E9. Telephone 613-761-4169, fax 613-761-5209, e-mail norse@cyberus.ca 


\section{La dexaméthasone intraveineuse permet-elle de prévenir les nausées et les vomissements après une plastie mammaire de réduction?}

CONTEXTE : Les nausées et les vomissements postopératoires (NVP) sont fréquents et très incommodants chez les patientes ayant subi une plastie mammaire de réduction. Ils peuvent même retarder le congé de l'hôpital. La dexaméthasone est un antiémétique efficace, très souvent utilisé.

OBJECTIF : L'étude visait à évaluer l'efficacité de la dexaméthasone seule pour réduire la fréquence des NVP chez les patientes opérées pour une plastie mammaire de réduction.

MÉTHODE : Cinquante femmes devant subir une plastie mammaire de réduction ont reçu au hasard soit de la dexaméthasone par voie intraveineuse (i.v.) à raison de $0,150 \mathrm{mg} / \mathrm{kg}$, soit une solution saline avant l'induction de l'anesthésie. L'analgésie postopératoire était assurée par l'administration i.v. de morphine, commandée par la patiente et par l'administration rectale d'indométhacine. La présence ou l'absence de nausées, de haut-le-coeur et de vomissements ainsi que l'intensité de la douleur ont été évaluées à l'arrivée au service de soins postanesthésiques, puis $2 \mathrm{~h}, 6 \mathrm{~h}, 8 \mathrm{~h}$ et $12 \mathrm{~h}$ plus tard. Il y a eu également une entrevue téléphonique $24 \mathrm{~h}$ et $48 \mathrm{~h}$ après l'intervention.

RÉSUTATS : Les caractéristiques des deux groupes en ce qui concerne l'âge, les antécédents de mal des transports, la durée de l'anesthésie et l'utilisation des opioïdes étaient similaires, et ce, tant pendant l'opération qu'après. Aucune différence quant à l'incidence des NVP n'a été observée entre les deux groupes, mais les patientes qui avaient reçu de la dexaméthasone ont eu moins souvent besoin d'antiémétiques d'appoint. CONCLUSION : L'administration i.v. de dexaméthasone avant l'induction de l'anesthésie s'avère inefficace comme antiémétique seul à des fins prophylactiques chez les femmes devant subir une plastie mammaire de réduction. t is important to avoid postoperative nausea and vomiting L(PONV) because patients report greater satisfaction with in-hospital care when effective antiemetic prophylaxis has been provided. Additionally, persistent nausea and vomiting can delay discharge from hospital $(1,2)$. Breast surgery is associated with a high $(40 \%$ to $70 \%)$ incidence of PONV $(3,4)$.

Preoperative administration of the five hydroxytryptamine antagonist, ondansetron, reduces the incidence of PONV in breast surgery (5-7). This class of drugs, which includes ondansetron and granisetron, is relatively expensive for routine administration as a prophylactic antiemetic (8). Prophylaxis with less expensive alternatives such as droperidol and metoclopramide has not proven effective (9). Dexamethasone is an inexpensive and effective antiemetic with a long duration of action (10). Dexamethasone, when combined with granisetron, reduces the incidence of PONV following breast surgery (11).

The purpose of this double-blind, randomized, placebo controlled study was to determine if intravenous dexamethasone alone would reduce the incidence of PONV following reduction mammoplasty.

\section{METHODS}

After approval from the Ottawa Hospital Research Ethics Board, 50 women were enrolled in the study. Women 18 years of age or older, of American Society of Anesthesiologists class 1 or 2, and scheduled for reduction mammoplasty were included in the trial. Women who weighed more than $100 \mathrm{~kg}$, those with a history of substance abuse, gastroesophageal reflux or allergy to morphine, and those taking hormone replacement therapy were excluded.

The patients were recruited during their visit to the preadmission unit and assigned either intravenous dexamethasone $(0.150 \mathrm{mg} / \mathrm{kg})$ or a similar volume of $0.9 \%$ saline using a computer generated random numbers table and sealed opaque envelopes.

The patients did not receive premedication. Intravenous access was secured in the operating room, and standard monitoring was applied. The patients received the study drug (dexamethasone) or the placebo before the induction of anesthesia, with patient, surgeon and anesthesiologist blinded to treatment allocation. Anesthesia was induced with midazolam $0.03 \mathrm{mg} / \mathrm{kg}$, fentanyl $1 \mu \mathrm{g} / \mathrm{kg}$, and propofol 2 to $5 \mathrm{mg} / \mathrm{kg}$. Following the induction of anesthesia, a laryngeal mask was inserted and spontaneous ventilation allowed. Anesthesia was maintained with nitrous oxide/oxygen/isoflurane and intravenous fentanyl $1 \mu \mathrm{g} / \mathrm{kg} / \mathrm{hr}$. Anesthesia was discontinued at the completion of the surgery. Patients breathed 100\% oxygen until they regained consciousness. The laryngeal mask airway was removed when the patients were awake. The patients were then transferred to the postanesthesia care unit (PACU) where they received intravenous morphine via a patient controlled analgesia (PCA) device. This was programmed to deliver a $1 \mathrm{mg}$ bolus of morphine, with a 5 min lockout period. Four hours after surgery all patients received indomethacin $100 \mathrm{mg}$ per rectum. The PCA was discontinued at $5 \mathrm{~h}$ after surgery if the morphine consumption was less than $3 \mathrm{mg} / \mathrm{hr}$. Rescue antiemetic medication, dimenhydrinate $25 \mathrm{mg}$, was given intravenously if required. The patients received intravenous ondansetron $4 \mathrm{mg}$ if there was no relief from the nausea or vomiting $15 \mathrm{~min}$ after the administration of the dimenhydrinate.

Demographic data collected included age, height, weight, duration of surgery, total volume of intravenous crystalloid infused intraoperatively, and estimated blood loss. The presence or absence of nausea, retching and vomiting were assessed on arrival in the PACU, and thereafter at 2, 6, 9 and $12 \mathrm{~h}$ after arrival in the PACU. Pain was assessed using a verbal analogue pain score (VAPS) at the same intervals. A VAPS of zero represents no pain, and a VAPS of 10 repesents the worst pain imaginable. The hourly and total consumption of morphine was recorded. Patients were also interviewed over the telephone at 24 and $48 \mathrm{~h}$ to assess nausea, vomiting and the use of supplemental analgesia, and to obtain a global verbal pain rating for the day. 
TABLE 1

Patient characteristics and perioperative analgesic use

\begin{tabular}{|c|c|c|c|}
\hline Characteristic & Dexamethasone & Placebo & $\mathbf{P}$ \\
\hline Number of patients & 25 & 25 & \\
\hline Age (years) & $36.5 \pm 12.6$ & $38.5 \pm 10.3$ & 0.535 \\
\hline Weight (kg) & $71.7 \pm 11.7$ & $75.8 \pm 14.4$ & 0.277 \\
\hline $\begin{array}{l}\text { History of PONV and } \\
\text { motion sickness }\end{array}$ & lor & 6 & 0.999 \\
\hline $\begin{array}{l}\text { Duration of } \\
\text { anesthesia (min) }\end{array}$ & $120.5 \pm 20.2$ & $124.5 \pm 17.5$ & 0.462 \\
\hline Tissue excised (gm) & $1553.0 \pm 842.7$ & $1433.2 \pm 607.3$ & 0.567 \\
\hline $\begin{array}{l}\text { Intraoperative } \\
\text { fentanyl (mcg) }\end{array}$ & $217.8 \pm 53.0$ & $235 \pm 58.0$ & 0.271 \\
\hline $\begin{array}{l}\text { Postoperative } \\
\text { fentanyl (mcg) }\end{array}$ & $62.0 \pm 57.3$ & $73.0 \pm 65.0$ & 0.52 \\
\hline $\begin{array}{l}\text { Postoperative } \\
\text { morphine (mg) }\end{array}$ & $7.8 \pm 9.1$ & $10.1 \pm 9.8$ & 0.39 \\
\hline
\end{tabular}

Values expressed as mean $\pm S D$. PONV Postoperative nausea and vomiting

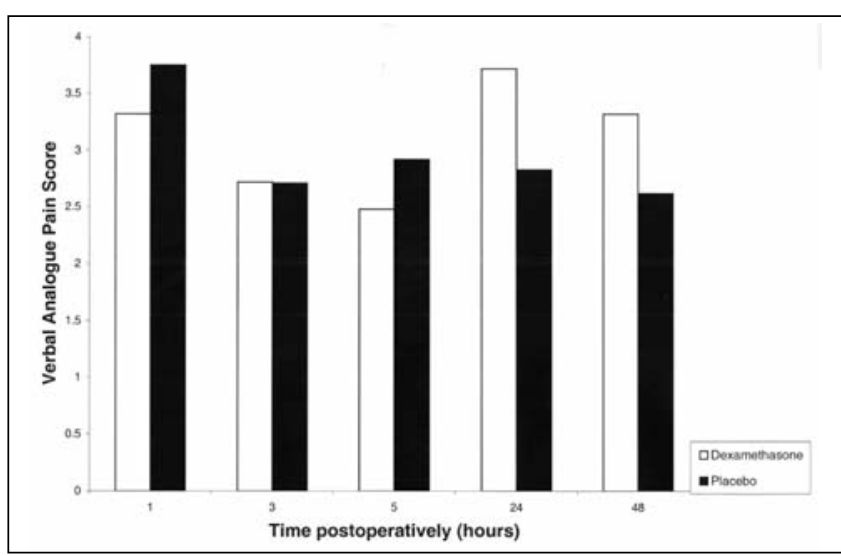

Figure 1) Verbal analogue pain scores

Demographic data and total analgesic consumption were analyzed using unpaired Student's t-tests. The incidence of PONV was compared using $\chi^{2}$ statistics, while verbal pain scores and analgesic consumption over time were assessed using repeated measures analysis of variance.

\section{RESULTS}

Fifty women were enrolled in the study and completed the study protocol. Complete 48-h follow-up was available on all patients, except for one patient in the placebo group. She experienced nausea without vomiting in the early postoperative period but was lost to follow-up after being discharged from the hospital.

There were no significant differences in demographic characteristics and postoperative opioid consumption (Table 1). Verbal pain scores were similar $(\mathrm{P}=0.747)$ in both groups throughout the postoperative period (Figure 1).
TABLE 2

Postoperative nausea and vomiting

\begin{tabular}{lccc}
\hline & $\begin{array}{c}\text { Dexamethasone } \\
\mathbf{n}(\%)\end{array}$ & $\begin{array}{c}\text { Placebo } \\
\mathbf{n}(\%)\end{array}$ & $\mathbf{P}$ \\
\hline Nausea 0-3 h & $8(32)$ & $12(48)$ & 0.248 \\
Vomiting 0-3 h & $3(12)$ & $2(8)$ & 0.999 \\
Nausea 0-48 h & $17(68)$ & $20(80)$ & 0.212 \\
Vomiting 0-48 h & $6(24)$ & $6(25)$ & 0.999 \\
\hline
\end{tabular}

The incidence of postoperative nausea and vomiting in the early and late postoperative periods was similar in both groups (Table 2). However, dexamethasone reduced the proportion of patients receiving rescue antiemetics (36\% versus $76 \%, \mathrm{P}=0.004)$ and the total number of doses of ondansetron received ( 12 versus $33, \mathrm{P}=0.007$ ) to treat $\mathrm{PONV}$.

\section{DISCUSSION}

Preoperative, prophylactic administration of intravenous dexamethasone does not reduce the overall incidence of PONV following reduction mammoplasty. There was a trend toward a reduced incidence of PONV during the postanesthesia care unit stay, but these results were not statistically significant. The group that received preoperative dexamethasone required fewer rescue antiemetics than did the placebo group, despite having experienced a similar incidence and severity of PONV.

Eighty per cent of patients receiving placebo in this study suffered from PONV, which is consistent with similar research in this field (12). Risk factors for PONV include being female, nonsmoking and a past history of PONV or motion sickness (13).

Dexamethasone has a delayed onset of action. When used as single agent prophylaxis for total abdominal hysterectomy, it is more effective when given before induction, rather than before the patient's emergence from anesthesia (14). Dose ranging studies have shown that doses less than $5 \mathrm{mg}$ are not more efficacious than placebo (15). The mechanism of action of dexamethasone is poorly understood. Its antiemetic effect may result from the inhibition of prostaglandin synthesis, enhanced endorphin release or sensitization of the receptor to other pharmacological agents (10). The latter effect may explain the reduction in consumption of rescue antiemetics in the group that received dexamethasone.

A multimodal approach to the prevention of PONV can be extremely effective. Scuderi et al (16) were able to reduce the incidence of PONV in patients undergoing gynecological laparoscopy to $2 \%$. They adopted a protocol of intravenous hydration, propofol-remifentanil anesthesia, pre-emptive analgesia with ketorolac, and antiemetic prophylaxis with a combination of ondansetron, dexamethasone and droperidol. 


\section{CONCLUSIONS}

For women undergoing reduction mammoplasty, single agent antiemetic prophylaxis is inadequate for the reliable prevention of PONV. The high prevalence of PONV following hospital discharge suggests that antiemetic drug regimens must extend at least $24 \mathrm{~h}$ into the postoperative period. A multimodal, long term strategy for antiemetic prophylaxis may be required to reduce the incidence of $\mathrm{PONV}$ in this high risk group of patients.

\section{REFERENCES}

1. Macario A, Weinger M, Carney S, Kim A. Which clinical anesthesia outcomes are important to avoid? The perspective of patients. Anesth Analg 1999;89:652-8.

2. Hill RP, Lubarsky DA, Phillips-Bute B, et al. Cost-effectiveness of prophylactic antiemetic therapy with ondansetron, droperidol, or placebo. Anesthesiology 2000;92:958-67.

3. Sinclair DR, Chung F, Mezei G. Can postoperative nausea and vomiting be predicted? Anesthesiology 1999;91:109-18.

4. Karlsen KL, Persson E, Wennberg E, Stenqvist O. Anaesthesia, recovery and postoperative nausea and vomiting after breast surgery. A comparison between desflurane, sevoflurane and isoflurane anaesthesia. Acta Anaesthesiol Scand 2000;44:489-93.

5. Chan MT, Chui PT, Ho WS, King WW. Single-dose tropisetron for preventing postoperative nausea and vomiting after breast surgery. Anesth Analg 1998;87:931-5.

6. Fujii Y, Tanaka H, Toyooka H. Granisetron reduces incidence of nausea and vomiting after breast surgery. Acta Anaesthesiol Scand 1997;41:746-9.

7. Sadhasivam S, Saxena A, Kathirvel S, Kannan TR, Trikha A,
Mohan V. The safety and efficacy of prophylactic ondansetron in patients undergoing modified radical mastectomy. Anesth Analg 1999;89:1340-5.

8. Tramer MR, Phillips C, Reynolds DJ, McQuay HJ, Moore RA. Costeffectiveness of ondansetron for postoperative nausea and vomiting. Anaesthesia 1999;54:226-34.

9. Fujii Y, Tanaka H, Toyooka H. Prevention of nausea and vomiting in female patients undergoing breast surgery: A comparison with granisetron, droperidol, metoclopramide and placebo. Acta Anaesthesiol Scand 1998;42:220-4.

10. Henzi I, Walder B, Tramer MR. Dexamethasone for the prevention of postoperative nausea and vomiting: A quantitative systematic review. Anesth Analg 2000;90:186-94.

11. Fujii Y, Tanaka H, Toyooka H. Prophylactic antiemetic therapy with granisetron-dexamethasone combination in women undergoing breast surgery. Acta Anaesthesiol Scand 1998;42:1038-42.

12. Rosaeg OP, Bell M, Cicutti NJ, Dennehy KC, Lui AC, Krepski B. Pre-incision infiltration with lidocaine reduces pain and opioid consumption after reduction mammoplasty. Reg Anesth Pain Med 1998;23:575-9.

13. Apfel CC, Laara E, Koivuranta M, Greim CA, Roewer N A simplified risk score for predicting postoperative nausea and vomiting: Conclusions from cross-validations between two centers. Anesthesiology 1999;91:693-700.

14. Wang JJ, Ho ST, Tzeng JI, Tang CS. The effect of timing of administration of dexamethasone administration on its efficacy as a prophylactic antiemetic for post-operative nausea and vomiting. Anesth Analg 2000;91:136-9.

15. Wang JJ, Ho ST, Lee SC, Liu YC, Ho CM. The use of dexamethasone for preventing postoperative nausea and vomiting in females undergoing thyroidectomy: A dose-ranging study. Anesth Analg 2000;91:1404-7.

16. Scuderi PE, James RL, Harris L, Mims GR. Multimodal antiemetic management prevents early postoperative vomiting after outpatient laparoscopy. Anesth Analg 2000;91:1408-14. 